\title{
Enzymatic and immunological properties of Bungarus flaviceps (red-headed krait) venom
}

\section{Tan NH (1), Fung SY (1), Ponnudurai G (2)}

(1) Department of Molecular Medicine, School of Medicine, University of Malaya, Kuala Lumpur, Malaysia; (2) International Medical University, Kuala Lumpur, Malaysia.

ABSTRACT: Bungarus flaviceps (red-headed krait) venom presents an intravenous $\mathrm{LD}_{50}$ of $0.32 \mu \mathrm{g} / \mathrm{g}$ and exhibits enzymatic activities similar to other Bungarus toxins. ELISA cross-reactions between anti-Bungarus flaviceps and a variety of elapid and viperid venoms were observed in the current study. Double-sandwich ELISA was highly specific, since anti- $B$. flaviceps serum did not cross-react with any tested venom, indicating that this assay can be used for species diagnosis in $B$. flaviceps bites. In the indirect ELISA, anti- $B$. flaviceps serum cross-reacted moderately with three different Bungarus venoms (9-18\%) and Notechis scutatus venom, but minimally with other elapid and viperid toxins. The results indicated that $B$. flaviceps venom shares common epitopes with other Bungarus species as well as with $N$. scutatus. The lethality of the $B$. flaviceps venom was neutralized effectively by antiserum prepared against $B$. candidus and $B$. flaviceps toxins and a commercial bivalent elapid antivenom prepared against $B$. multicinctus and Naja naja atra venoms, but was not neutralized by commercial antivenoms prepared against Thai cobra, king cobra and banded krait. These data also suggested that the major lethal toxins of $B$. flaviceps venom are similar to those found in $B$. multicinctus and $B$. candidus venoms.

KEY WORDS: Bungarus flaviceps venom, enzymes, ELISA, neutralization.

CONFLICTS OF INTEREST: There is no conflict.

FINANCIAL SOURCE: Government of Malaysia.

\section{CORRESPONDENCE TO:}

NGET HONG TAN, Department of Molecular Medicine, School of Medicine, University of Malaya, Kuala Lumpur, Malaysia. Phone: +60 3 79674912. Fax: +60 3 79674957. Email: tanngethong@yahoo.com.sg. 


\section{INTRODUCTION}

Bungarus flaviceps (red-headed krait) is a rare snake found in Southeast Asia. It presents a very striking and distinctive coloration - namely a bright red head and tail with a black body that includes a low-lateral narrow bluish white stripe (Figure 1). The snake occurs in Burma, Thailand, Vietnam, Malaysia and Indonesia (1). The major lethal toxin having been isolated and cloned from Bungarus flaviceps is considered a novel isoform of $\beta$-bungarotoxin $(2,3)$. Its venom also contains a novel postsynaptic neurotoxin, termed $\mathrm{k}$-flavitoxin, which is a potent inhibitor of nicotinic transmission in autonomic ganglia $(4,5)$. The venoms of several common Bungarus species have been well investigated (6-8). Little, however, is known about the enzymatic properties of the Bungarus flaviceps venom. Chanhome et al. (9) reported that a commercial Bungarus fasciatus antivenom could neutralize the lethal toxicity of $B$. flaviceps venom. The immunological cross-reactivity of this venom, however, has not been investigated. We report herein a preliminary study on the enzymatic activities of $B$. flaviceps venom and its immunological cross-reactivities using enzyme-linked immunosorbent assay (ELISA).

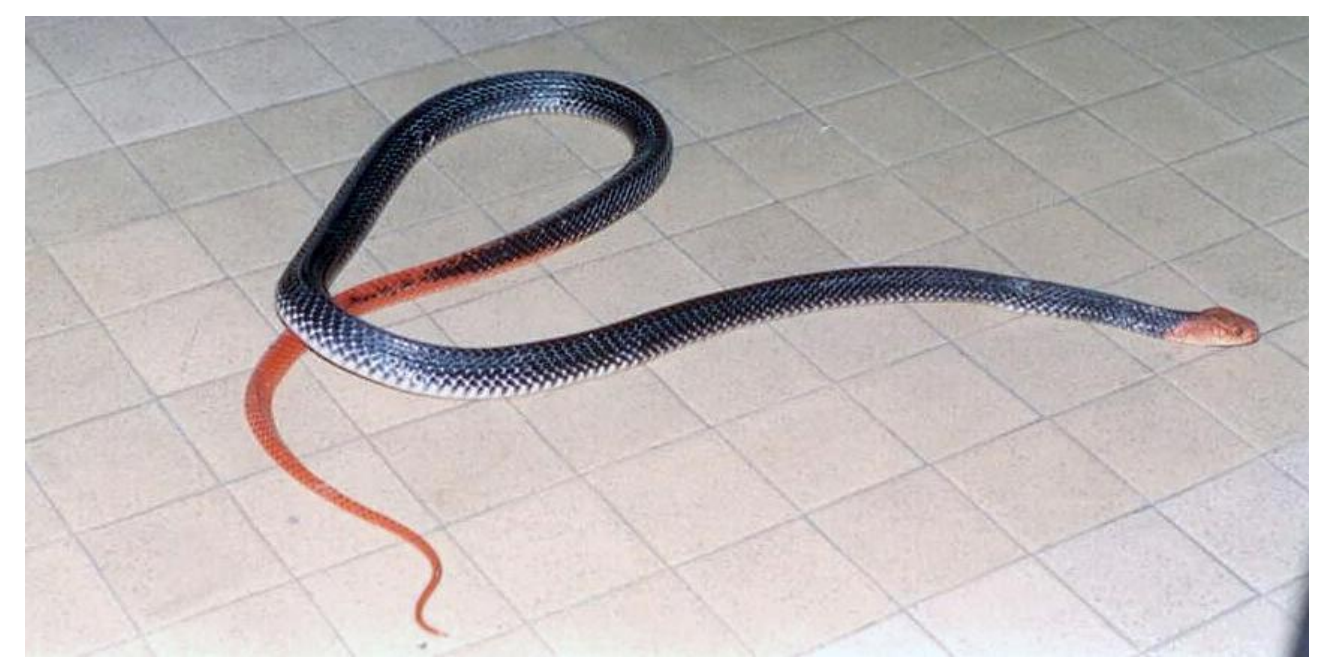

Figure 1. An adult Bungarus flaviceps snake. The snake was approximately 6 feet in length; the head and tail were bright red while the body was black with a narrow bluish white stripe low on its side.

Bungarus flaviceps venom was obtained from a single milking of an adult individual (Figure 1) captured in central Malaysia. Venom yield was $50 \mathrm{mg}$ dry weight. Other types of snake venoms used in this study were obtained from the Miami 
Serpentarium Laboratories (USA), Latoxan (France) and Venom Supplies (Australia). All reagents, enzyme substrates and chemicals were purchased from Sigma Chemical Company (USA) or Bio-Rad Laboratories (USA). Monovalent antivenoms against Ophiophagus hannah (king cobra), Naja kaouthia (Thai cobra) and Bungarus fasciatus (banded krait) were obtained from the Thai Red Cross Society (TRCS), Bangkok, Thailand. Bivalent elapid antivenom (NIPM elapid antivenom, prepared against Bungarus multicinctus and Naja naja atra) was obtained from the National Institute of Preventive Medicine (NIPM), Taipei, Taiwan.

Lethality, procoagulant and anticoagulant, hemorrhagic and enzymatic activities were determined as previously described $(7,10)$. Monospecific rabbit antisera against Bungarus flaviceps, Bungarus fasciatus, Bungarus candidus (Malayan krait) and Notechis scutatus (Eastern tiger snake) were prepared using a hyperimmunization scheme (11). IgG antibodies and IgG-horseradish peroxidase conjugate were prepared according to Hudson and Hay (12) and Tijssen (13), respectively.

The indirect ELISA and double sandwich procedures were performed according to a previous description (14). The $L D_{50}$ value was calculated according to Weil (15). To determine the neutralization effect of the antiserum/antivenom, a quantity equivalent to $3.0 \mathrm{LD}_{50}$ of the venom, in $0.05 \mathrm{~mL}$ of saline solution, was mixed with $0.1-0.2 \mathrm{~mL}$ of antiserum (with appropriate dilution) and incubated for 30 minutes at $37^{\circ} \mathrm{C}$. After centrifugation, the supernatant was injected intravenously into the tail vein of ICR mice. Mortality after 24 hours was determined $(n=6)$. The rabbits and mice were supplied by the Central Animal House, School of Medicine, University of Malaya, Kuala Lumpur, Malaysia.

The intravenous $L D_{50}$ of the $B$. flaviceps venom was determined to be $0.32 \mu \mathrm{g} / \mathrm{g}$ in mouse, a value comparable to $B$. caeruleus venom $(0.13-0.23 \mu \mathrm{g} / \mathrm{g})$ but higher than that of $B$. candidus and $B$. multicinctus venoms $(0.04-0.13 \mu \mathrm{g} / \mathrm{g})$ and lower than that of $B$. fasciatus venom (1.2-1.4 $\mu \mathrm{g} / \mathrm{g})(16)$. The $L D_{50}$ reported herein is slightly higher than an earlier one reported by Chanhome et al. (9), which could be due to either geographic or individual variation.

B. flaviceps venom exhibited enzymatic properties similar to other Bungarus venoms (Table 1), including proteolytic, phosphodiesterase, alkaline phosphomonosterase, Lamino acid oxidase, acetylcholinesterase, phospholipase A, 5'-nucleotidase and hyaluronidase activities. Particularly noteworthy are its very low protease and high 
acetylcholinesterase and phospholipase $A_{2}$ activities, characteristic of venoms from the genus Bungarus (15). Like the other Bungarus venoms, it did not exhibit hemorrhagic, procoagulant or anticoagulant activity in vitro.

Table 1. Enzymatic properties of Bungarus flaviceps and some other Bungarus venoms

\begin{tabular}{l|c|c|c|c|c|c|c|c}
\hline Species & PRO & PDE & PME & LAAO & ACE & PLA & NUC & HYA \\
\hline B. flaviceps & 0.7 & 10 & 1 & 60 & 72 & 968 & 1.6 & 62 \\
\hline B. caeruleus & $0.3-0.8$ & $1-2$ & $2-8$ & $69-228$ & $26-43$ & $665-1097$ & $1.1-2.1$ & $332-406$ \\
\hline B. candidus & $0.5-0.7$ & $1-2$ & $2-5$ & $171-292$ & $42-85$ & $339-732$ & trace & $418-544$ \\
\hline B. multicinctus & $0.2-0.4$ & $1-3$ & $4-13$ & $20-89$ & $14-30$ & $208-333$ & trace & $59-277$ \\
\hline B. fasciatus & $0.3-0.5$ & $4-6$ & $2-3$ & $65-176$ & $12-36$ & $297-379$ & $3.4-3.6$ & $4-33$ \\
\hline
\end{tabular}

PRO: protease (unit/mg) - one unit is equal to an increase of one absorbance unit per hour at $280 \mathrm{~nm}$; PDE: phosphodiesterase (nmole/min/mg); PME: alkaline phosphomonoesterase $(\mathrm{nmole} / \mathrm{min} / \mathrm{mg}$ ); LAAO: L-amino acid oxidase (nmole/min/mg); ACE: acetylcholine esterase $(\mu \mathrm{mole} / \mathrm{min} / \mathrm{mg})$; PLA: phospholipase A ( $\mu \mathrm{mole} / \mathrm{min} / \mathrm{mg})$; NUC: 5'-nucleotidase $(\mu \mathrm{mole} / \mathrm{min} / \mathrm{mg})$; HYA: hyaluronidase (NFU/mg) (NFU: National Formulary Unit). The substrates used were casein, bis-4-nitrophenyl phosphate, 4-nitrophenyl phosphate, L-leucine, acetylthiocholine, egg yolk suspension, 5'-AMP and human umbilical cord hyaluronic acid, respectively. Data for B. caeruleus, B. candidus, B. multicinctus, and $B$. fasciatus venoms are from Tan and Ponnudurai (7).

Both the indirect and double-sandwich ELISA procedures for $B$. flaviceps venom yielded an exponential dose-response curve at venom concentrations from $3 \mathrm{ng} / \mathrm{mL}$ to $100 \mathrm{ng} / \mathrm{mL}$ (not shown). The ELISA cross-reactions between antibodies against $B$. flaviceps venom and 28 venoms from snakes of the families Viperidae and Elapidae are shown in Table 2. The double-sandwich ELISA for B. flaviceps venom was highly specific: there were minimum cross-reactions between the $\lg G$ anti- $B$. flaviceps antibodies to all the venoms tested. Thus, double sandwich ELISA can be used for species diagnosis in B. flaviceps bite. In the indirect ELISA procedure, there were also no substantial cross-reactions between the antibodies and the various snake venoms tested, except for some venoms from the same genus, Bungarus, and the genus Notechis. It is interesting to note that venom from the Australian elapid, Notechis scutatus, yielded a very high level of indirect ELISA cross-reactions (45\%) with anti-B. flaviceps, while venoms of $B$. candidus and $B$. multicinctus yielded only low cross-reaction proportions (5-9\%), indicating that $B$. flaviceps venom shares more common epitopes with $N$. scutatus venom than with the two venoms from the same Bungarus genus. This is another illustration of how venoms from unrelated 
snakes may share common antigens (17). A surprising feature is the total lack of indirect ELISA cross-reactions between anti-B. flaviceps and venoms of Naja, Ophiophagus hannah and Enhydrina schistosa under the experimental conditions. Both $B$. flaviceps venom and these elapid venoms contain high phospholipase $A_{2}$ content (8). While prior investigations of the immunological relationships presented by snake venom phospholipase $A_{2}$ indicated that elapid phospholipases $A_{2}$ were antigenically similar (18), our results suggest that the major $B$. flaviceps phospholipase $A_{2}$ may exhibit unique antigenic characteristics that differ substantially from venom phospholipases $A_{2}$ from the other elapids including Naja, O. hannah and E. schistosa.

Table 2. Cross-reactivity between antibodies to Bungarus flaviceps venom and various snake venoms in the indirect and double-sandwich ELISA of the venom

\begin{tabular}{c|c|c}
\hline \multirow{2}{*}{ Venom } & \multicolumn{2}{|c}{$\begin{array}{r}\text { Absorbance as \% of B. flaviceps venom } \\
\text { (mean } \pm \text { SD, } \mathbf{n}=6-9)\end{array}$} \\
\cline { 2 - 3 } & Indirect ELISA & Double-sandwich ELISA \\
\hline Bungarus flaviceps & 100 & 100 \\
\hline Family Viperidae & & 0 \\
\hline Agkistrodon p. piscivorus & 0 & 0 \\
\hline Calloselasma rhodostoma & 0 & 0 \\
\hline Bothrops asper & $4.3 \pm 0.8$ & 0 \\
\hline Bothrops atrox & $2.9 \pm 0.5$ & 0 \\
\hline Crotalus adamanteus & $4.1 \pm 0.2$ & 0 \\
\hline Crotalus atrox & 0 & 0 \\
\hline Sistrurus c. tergeminus & 0 & 0 \\
\hline Protobothrops flavoviridis & 0 & 0 \\
\hline Cryptelytrops albolabris & 0 & 0 \\
\hline Cryptelytrops purpureomaculatus & 0 & 0 \\
\hline Parais sumatranus & $5.0 \pm 0.7$ & 0 \\
\hline Popeia popeorium & 0 & 0 \\
\hline Tropidolaemus wagleri & 0 & 0 \\
\hline Echis carinatus & 0 & 0 \\
\hline Vipera a. ammodytes & 0 & 0 \\
\hline Daboia r. siamensis & 0 & \\
\hline Family Elapidae & & \\
\hline & &
\end{tabular}


Tan NH et al. Enzymatic and immunological properties of Bungarus flaviceps (red-headed krait) venom. J Venom Anim Toxins incl Trop Dis. 2010;16(1):152

\begin{tabular}{c|c|c}
\hline Bungarus candidus & $8.6 \pm 1.2$ & 0 \\
\hline Bungarus caeruleus & $17.6 \pm 2.2$ & $1.7 \pm 0.2$ \\
\hline Bungarus multicinctus & $5.1 \pm 2.0$ & 0 \\
\hline Bungarus fasciatus & $18.4 \pm 0.3$ & $4.3 \pm 0.6$ \\
\hline Naja sputatrix & 0 & 0 \\
\hline Naja kaouthia & 0 & 0 \\
\hline Ophiophagus hannah & 0 & 0 \\
\hline Dendroaspis angusticeps & 0 & 0 \\
\hline Notechis scutatus & $45.3 \pm 1.5$ & $1.5 \pm 1.1$ \\
\hline Notechis ater ater & $6.2 \pm 2.4$ & $\mathrm{ND}$ \\
\hline Hoplocephalus stephensis & 0 & 0 \\
\hline Enhydrina schistosa & 0 & 0 \\
\hline
\end{tabular}

The indirect ELISA mixture contained $100 \mu \mathrm{L}$ of venom $(25 \mathrm{ng} / \mathrm{mL}), 100 \mu \mathrm{L}$ of anti-B. flaviceps venom $(1: 10000)$ and $100 \mu \mathrm{L}$ of conjugate (1:4000). The absorbance at $492 \mathrm{~nm}$ for $B$. flaviceps venom was $1.33 \pm 0.08$ with anti- $B$. flaviceps venom. The double-sandwich ELISA mixture contained $100 \mu \mathrm{L}$ of IgG anti- B. flaviceps venom $(2 \mu \mathrm{g} / \mathrm{mL})$ and $100 \mu \mathrm{L}$ of conjugate (1:2000). Absorbance at $492 \mathrm{~nm}$ was $0.728 \pm 0.03$. ND: not determined.

Laboratory-prepared monospecific rabbit anti-B. flaviceps, anti- $B$. candidus and the commercial NIPM bivalent elapid antivenom were effective in neutralizing the lethal effect of the venom in mice; the amounts of $B$. flaviceps venom neutralized by these three antisera were $1600 \mu \mathrm{g} / \mathrm{mL}$ (167 LD 50 's per $\mathrm{mL}$ ), $400 \mu \mathrm{g} / \mathrm{mL}$ (42 LD 50 's per mL) and $6667 \mu \mathrm{g} / \mathrm{mL}$ (695 LD 50 's per $\mathrm{mL}$ ), respectively, for anti-B. flaviceps, anti-B. candidus and NIPM bivalent elapid antivenom, which was known to neutralize $B$. multicinctus venom effectively (19). The other two laboratory-prepared monospecific rabbit antisera (anti- $B$. fasciatus and anti- $N$. scutatus) and three commercial Thai Red Cross Society antivenoms (king cobra antivenom, Thai cobra antivenom and banded krait antivenom) all failed to protect the mice even when $200 \mu \mathrm{L}$ of the antiserum was injected per mouse. Our results, however, are in contrary to that of Chanhome (9), who reported that the Thai Red Cross Society antivenom developed against banded krait ( $B$. fasciatus) could effectively neutralize $B$. flaviceps venom. The reason for this discrepancy is not clear but it could be due to geographic/individual variation.

It is interesting to note that in the indirect ELISA, both $B$. fasciatus and $N$. scutatus venoms cross-reacted strongly (18\%) with anti- $B$. flaviceps, while both $B$. candidus and $B$. multicinctus venoms yielded rather low cross-reaction levels $(<9 \%)$. This lack of correlation between antigenic similarity and neutralizing capacity of snake venoms 
has been reported by many other authors (16). These data also suggest that the major lethal toxins of $B$. flaviceps venom are similar to those found in $B$. multicinctus and $B$. candidus venoms, that is, polypeptide neurotoxins and phospholipase $A_{2}$ toxins $(8,20)$. Khow et al. (2) have indeed shown that the major lethal toxin of $B$. flaviceps venom was similar to $\beta$-bungarotoxin from $B$. multicinctus venom.

ACKNOWLEDGMENTS: This work was supported by research grants, IRPA-3-0704-097 and RG 088/09HTM from the government of Malaysia.

\section{REFERENCES}

1. Tweedie MWF. The snakes of Malaya. $3^{\text {rd }}$ ed. Singapore: Singapore National Printers (Pte) Ltd; 1983. 167p.

2. Khow O, Chanhome L, Omori-Satoh T, Sitprija V. Isolation of the major lethal toxin in the venom of Bungarus flaviceps. Toxicon. 2002;40(4):463-9.

3. Yanoshita R, Ogawa Y, Murayama N, Omori-Satoh T, Saguchi K, Higuchi S, et al. Molecular cloning of the major lethal toxins from two kraits (Bungarus flaviceps and Bungarus candidus). Toxicon. 2006;47(4):416-24.

4. Chiappinelli VA, Wolf KM, DeBin JA, Holt IL. Kappa-flavitoxin: isolation of a new neuronal nicotinic receptor antagonist that is structurally related to kappabungarotoxin. Brain Res. 1987;402(1):21-9.

5. Grant GA, Frazier MW, Chiappinelli VA. Amino acid sequence of kappa-flavitoxin: establishment of a new family of snake venom neurotoxins. Biochemistry. 1988;27(10):3794-8.

6. Mirajkar KK, More S, Gadag JR. Preliminary studies with a neurotoxin obtained from Bungarus caeruleus venom. J Venom Anim Toxins incl Trop Dis. 2006;12(1):7890.

7. Tan NH, Ponnudurai G. Biochemical characterization of snake venoms. In: Gopalakrishnakone P, Tan CK, editors. Recent advances in toxinology research. Singapore: Venom \& Toxin research group; 1992. p. 210-59. 1 vol.

8. Karlsson E. Chemistry of protein toxins in snake venoms. In: Lee CY, editor. Handbook of experiment pharmacology. Berlin: Springer-Verlag; 1979. p. 159-212. 52 vols. 
9. Chanhome L, Wongtongkam N, Khow O, Pakmanee N, Omori-Satoh T, Sitprija V. Genus specific neutralization of Bungarus snake venoms by Thai red cross banded krait antivenom. J Nat Toxins. 1999;8(1):135-40.

10. Tan NH, Ponnudurai G. A comparative study of the biological activities of venoms from snakes of the genus Agkistrodon (moccasins and copperheads). Comp Biochem Physiol B. 1990;95(3):577-82.

11. Tan NH. Improvement of Malayan cobra (Naja naja sputatrix) antivenin. Toxicon. 1983;21(1):75-9.

12. Hudson L, Hay FC. Practical immunology. $4^{\text {th }}$ ed. Oxford: Blackwell Scientific Publications; $1980.358 \mathrm{p}$.

13. Tijssen P. Preparation of enzyme-antibody or other enzyme macromolecules conjugates. In: Burdon $\mathrm{RH}$, van Knippenberg $\mathrm{PH}$, editors. Practice and theory of enzyme immunoassays. Amsterdam: Elsevier; 1985. p. 221-78.

14. Tan $\mathrm{NH}$, Yeo KH, Nik Jaafar MI. The use of enzyme-linked immunosorbent assay for the quantitation of Calloselasma rhodostoma (Malayan pit viper) venom and venom antibodies. Toxicon; 1992;30(12):1609-20.

15. Weil CS. Tables for convenient calculation of median-effective dose $\left(L D_{50}\right.$ or $\left.E_{50}\right)$ and instructions in their use. Biometrics. 1952;8(1):249-63.

16. Tan NH, Ponnudurai G. A comparative study on the biological properties of krait (Genus Bungarus) venoms. Comp Biochem Physiol C. 1990;95(1):105-9.

17. Minton SA Jr. Common antigens in snake venoms. In: Lee CY, editor. Handbook of experimental pharmacology. Berlin: Springer-Verlag; 1979. p. 845-62. 52 vols.

18. Middlebrook JL, Kaiser II. Immunological relationships of phospholipases $A_{2}$ neurotoxins from snake venoms. Toxicon. 1989;27(9):965-77.

19. Chieh-Fan C, Tzeng-Jih L, Wen-Chi H, Hua-Wei Y. Appropriate antivenom doses for six types of envenomations caused by snakes in Taiwan. J Venom Anim Toxins incl Trop Dis. 2009;15(3):479-90.

20. Tan $\mathrm{NH}$, Poh $\mathrm{CH}$, Tan CS. The lethal and biochemical properties of Bungarus candidus (Malayan krait) venom and venom fractions. Toxicon. 1989;27(9):1065-70. 